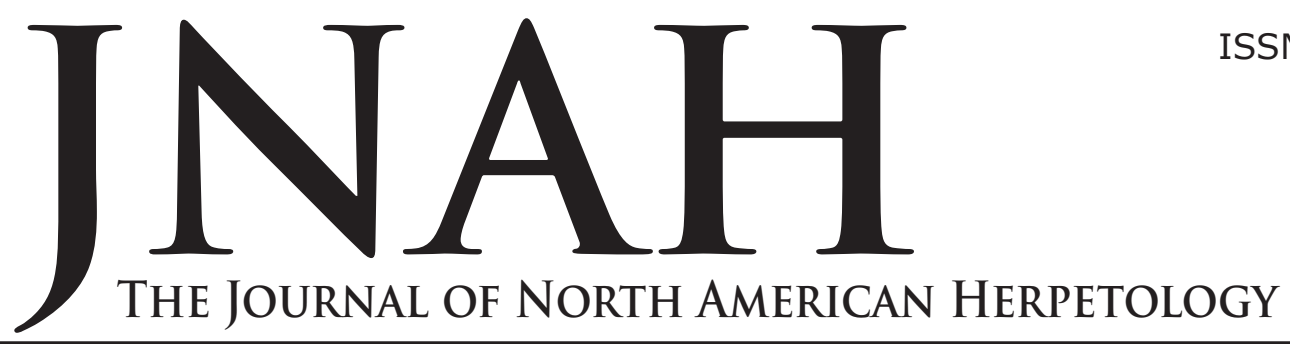

ISSN 2333-0694

Volume 2021, Number 1

June 2021

journals.ku.edu/jnah

\title{
DISTRIBUTION AND STATUS OF THE SUWANNEE COOTER, PSEUDEMYS CONCINNA SUWANNIENSIS, IN THE ALAFIA RIVER (HILLSBOROUGH COUNTY, FLORIDA, USA)
}

\author{
GEORGE L. HEINRICH ${ }^{1,2}$, TIMOTHY J. WALSH ${ }^{2,3}$, DALE R. JACKSON ${ }^{4}$, \\ AND J. SEAN DOODY 5
}

\author{
${ }^{1}$ Heinrich Ecological Services, 1213 Alhambra Way S., St. Petersburg, Florida 33705-4620, USA, \\ george@heinrichecologicalservices.com (corresponding author) \\ ${ }^{2}$ Florida Turtle Conservation Trust, 1213 Alhambra Way S., St. Petersburg, Florida 33705-4620, USA \\ ${ }^{3}$ Bruce Museum, 1 Museum Drive, Greenwich, Connecticut 06830, USA, \\ turtleconservationist@gmail.com \\ ${ }^{4}$ Florida Natural Areas Inventory, Florida State University, 1018 Thomasville Road, Suite 200-C, \\ Tallahassee, Florida 32303, USA, djackson@fnai.fsu.edu \\ ${ }^{5}$ University of South Florida, Department of Integrated Biology, St. Petersburg Campus, $1407^{\text {th }}$ \\ Avenue S., St. Petersburg, Florida 33701, USA, jseandoody@gmail.com
}

\begin{abstract}
The Suwannee Cooter, Pseudemys concinna suwanniensis, is a geographically limited turtle of conservation concern that inhabits Florida rivers draining into the northeastern Gulf of Mexico. Threats impacting its conservation status include take for human consumption, predation of turtles and nests, loss or degradation of nesting and basking habitat, water quality degradation, and boat strikes. Our surveys revealed that the Alafia River, which drains into Hillsborough Bay (northeastern Tampa Bay), is likely the stronghold of the southern distribution of $P$. c. suwanniensis. Multiple survey methods during 2015-2020 revealed that a substantial population of Suwannee Cooters inhabits much of this blackwater river system, including the main channel and at least one of its two primary tributaries. GIS analysis showed that more than half of the shoreline within the occupied extent is currently protected by conservation lands, although additional protection of private lands and improved habitat management protocols are needed to assure the population's conservation.
\end{abstract}

Key Words: Alafia River, anthropogenic threats, Pseudemys concinna, Suwannee Cooter, turtle conservation

INTRODUCTION

The Suwannee Cooter, Pseudemys concinna suwanniensis, is the largest emydid turtle in North America and occurs in river systems draining into the northeastern Gulf of Mexico from the Ochlockonee River in the eastern Florida panhandle, southward to Phillippi Creek in the southern peninsula (Figure 1; Heinrich et al. 2015, Heinrich and Walsh 2019). This principally riverine turtle exhibits prominent sexual dimorphism (adult females significantly larger than adult males) and is primarily herbivorous after the juvenile stage (Jackson and Walker 1997, Jackson, 2006). Threats to this species include take for human consumption (illegal in Florida since 2009), predation of turtles and nests, loss or degradation of nesting and basking habitat, water quality deg- radation, and boat strikes (Jackson 2006; Heinrich et al. 2010, 2012). Although delisted as a Species of Special Concern by the Florida Fish and Wildlife Conservation Commission in 2017, the agency has developed a species action plan as required for imperiled taxa (Florida Fish and Wildlife Conservation Commission 2013). The subspecies has been placed within various taxonomies by investigators (Seidel 1981, 1994; Ward 1984; Jackson 1995), with most authorities currently recognizing suwanniensis as a subspecies of $P$. concinna (Jackson 1995, 2002, 2006; Seidel and Dreslik 1996; Meylan 2006). We follow the taxonomy adopted by Meylan (2006) and the Turtle Taxonomy Working Group (2017). A Pseudemys taxonomy workshop organized by $\mathrm{H}$. Bradley Shaffer and Peter A. Scott (University of California, Los Angeles) in 


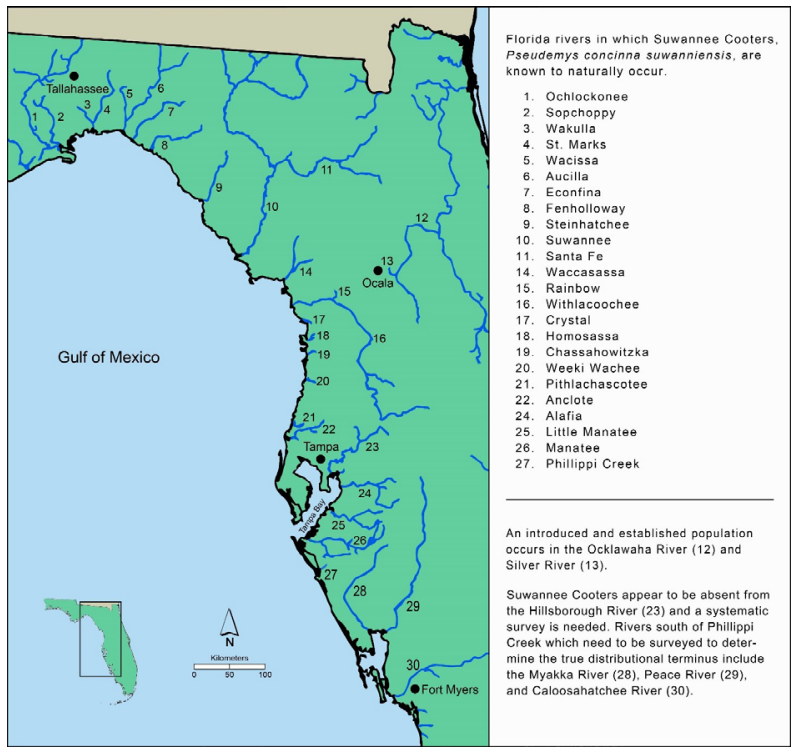

Fig. 1. Map of Florida rivers in which Pseudemys concinna suwanniensis occur, as well as rivers from which they are absent or unknown (Heinrich et al. 2015, Heinrich and Walsh 2016, 2019).

2019 addressed the need for a thorough revision of the genus.

Distribution and status of $P$. C. suwanniensis within its southern range has long been uncertain and hence of conservation concern. Publications as late as 2015 indicated a distributional gap of $\sim 79 \mathrm{~km}$ occurring between the Weeki Wachee River and Alafia River, long believed to be the southernmost limit of distribution (Heinrich et al. 2015). However, subsequent rapid assessment field surveys documented its occurrence within this hiatus in the Pithlachascotee and Anclote rivers (Walsh and Heinrich 2015, 2016). Apparent absence from the moderately large Hillsborough River (Marchand 1942, Jackson 2006), the only remaining river in this gap, calls for a thorough survey. Additional fieldwork south of the Alafia River documented $P$. C. suwanniensis in the Little Manatee River Manatee River, and Phillippi Creek (Heinrich and Walsh 2016, 2019). Rivers and streams to the south of Phillippi Creek need to be surveyed to determine the subspecies true distributional terminus. Although recent fieldwork noted above documented a range extension southward, those populations appear less dense. A range map in Krysko et al. (2019) shows a record of $P$. concinna south of the southernmost locality documented by Heinrich and Walsh (2019). The former record is based upon four specimens collected from Woodmere, Florida by Archie F. Carr on 18 November 1934 (UF 589-590, 594-595). Based on a different taxonomy in use at that time (e.g., Carr 1935, Pope 1939), we suspect these specimens may not represent what is currently recognized as $P$. concinna. Incomplete museum records and the Covid-19 pandemic of 2020 precluded us from accessing the specimens for identification. Further investigation is needed to clarify this problematic record.

The Alafia River is a moderately-sized blackwater system with water levels and flow heavily influenced by tidal fluctuations and seasonal rainfall (Figures 2-3). The river system flows through a mixture of natural and urban areas within a large phosphate mining region (Cardinale

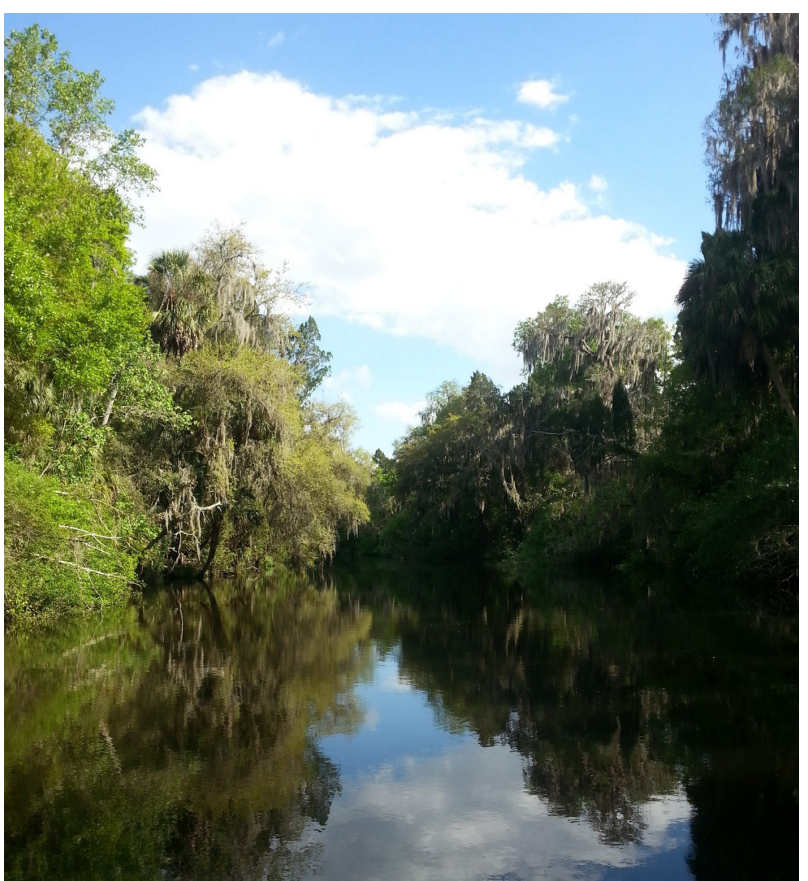

Fig. 2. Alafia River (Hillsborough County, Florida). Photograph by George L. Heinrich.

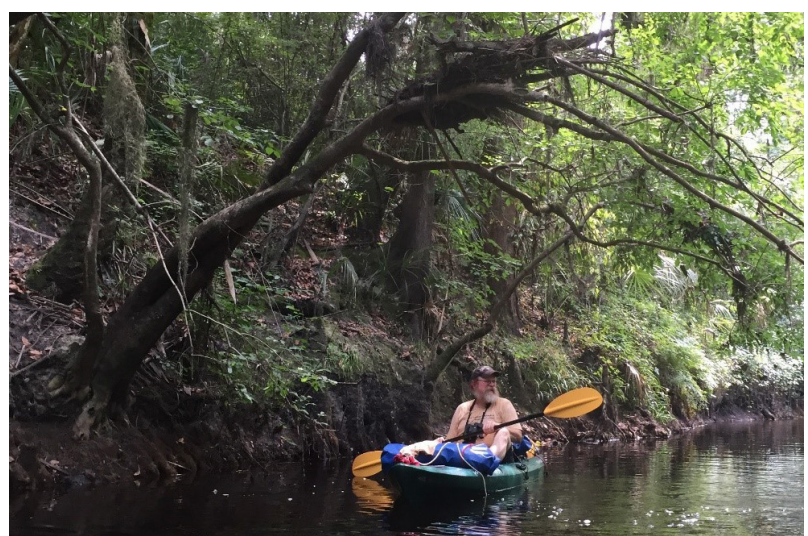

Fig. 3. Senior author surveying for turtles in the Alafia River (Hillsborough County, Florida). Note debris in overhead trees indicating higher water level in the past. Photograph by Timothy J. Walsh.

1998). The Alafia River basin and natural communities have been negatively impacted by anthropogenic activities, including mining, agriculture, and extensive residential and recreational development (Cardinale 1998, Heinrich et al. 2015). This river system supports three sympatric species in the genus Pseudemys: Suwannee Cooter, Peninsula Cooter ( $P$. floridana peninsularis), and Florida Red-bellied Cooter ( $P$. nelsoni). The earliest specimens of $P$. C. suwanniensis from the Alafia River were collected by Walter Auffenberg, Larry H. Ogren, and John W. Crenshaw, Jr. on 22 November 1953 (USNM 137634137635; Heinrich et al. 2015). Subsequent infrequent observations and specimens collected are summarized by Heinrich et al. (2015). The objectives of the study reported here were to determine the distribution and status of $P$. C. suwanniensis in the Alafia River. This effort builds upon our previous work in unstudied and understudied areas, and herein we present results of the 
first focused field investigation (2015-2020) at this site. Further, we compare the results and efficacy of multiple survey methods that we employed to identify locations of this species within the river system. Our methods and findings should be valuable to researchers planning further ecological studies and the latter will provide information allowing agencies to consider this species in habitat management and conservation efforts.

\section{STUDY AREA AND METHODS}

\section{Study Area}

The Alafia River has a watershed of $\sim 1,082 \mathrm{~km}^{2}$ (Stoker et al. 1996), mostly in eastern Hillsborough County, and is fed by two major tributaries originating in Polk County (Figure 4). The North Prong Alafia River flows westward where it merges with the South Prong Alafia River at Alderman's Ford Conservation Park (AFCP) in eastern Hillsborough County. From the conservation park, the Alafia River flows $\sim 37 \mathrm{~km}$ westward and empties into Hillsborough Bay (northeastern Tampa Bay) at Gibsonton (Parsons 2008). Lithia Spring Major and Buckhorn Main Spring (second magnitude springs) and their associated short spring runs feed into the normally tannic river (Scott et al. 2004). Tidal fluctuations influence the lower $\sim 18 \mathrm{~km}$ of the river which is heavily developed with residential properties and shoreline hardening (Cardinale 1998).

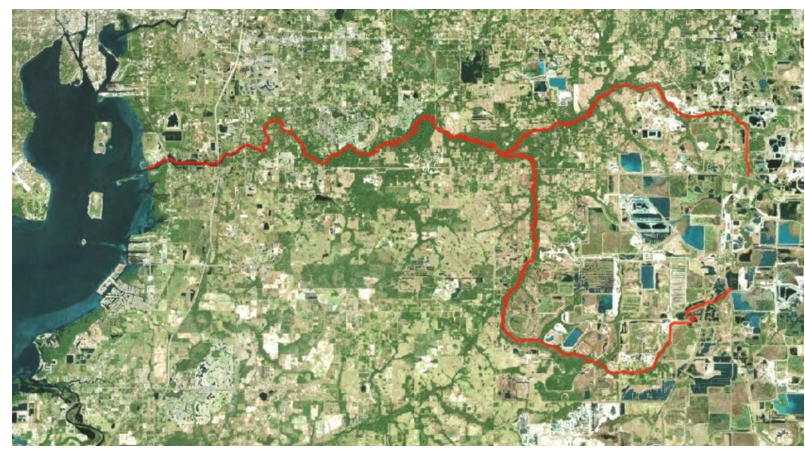

Fig. 4. Satellite map indicating Alafia River system (Hillsborough and Polk counties, Florida).

\section{Methods}

\section{Basking Survey from Land}

Google Earth and traditional maps (e.g., DeLorme Florida Atlas \& Gazetteer 2003) were utilized to identify 33 potential viewing points to monitor for all three species of Pseudemys basking along the shoreline of the Alafia River, including the North and South prongs. We conducted two reconnaissance trips $(8,14$ January 2015$)$ to assess habitat suitability for $P$. C. suwanniensis and to evaluate safe and legal access to sites. Based on these considerations, we selected 20 locations, all in Hillsborough County. Site selection excluded areas located upstream in Polk County as they appeared to lack appropriate habitat to support Suwannee Cooters. We used binoculars ( $8 \times 42)$, a spotting scope ( $80 \mathrm{~mm}, 20-60 x)$, and a digital camera (55-250 $\mathrm{mm}$ lens) to survey for basking turtles at the 20 monitored sites from 20 January-10 December 2015. Individual sites were visited by two observers (on all but one date) from 2-8 times throughout the year and no longer monitored once there was a confirmed sighting of $P$. C. suwanniensis. Fieldwork (all methods) was generally conducted from 900-1700 hours. We attempted to conduct survey work on sunny days to maximize basking behavior, and restricted fieldwork to weekdays to limit disturbance by recreational boaters. We recorded information for each Pseudemys observed similar to Enge and Wallace (2008): location using a hand-held Garmin GPS unit, estimated age class (juvenile, subadult, adult), sex (based on body size, foreclaw length, and tail length), and activity (basking on an embedded object [log or stick in the river not attached to the bank], basking on a sweeper [log or stick extending from the bank], basking on a floating log, basking on land, and floating or swimming).

\section{Basking Survey from Water}

We searched for all three species of Pseudemys in the Alafia River, including navigable sections of the North and South prongs, from a motorboat or kayaks. Lack of visible basking sites downriver from Williams Park at US 41 to where it empties into Hillsborough Bay precluded inclusion of this section. Two survey trips (10 March and 18 September 2015) were conducted by motorboat (two observers) between Bell Shoals Road and Williams Park, a span of $\sim 16 \mathrm{~km}$. The area from the convergence of the North and South prongs in AFCP downriver to Bell Shoals Road ( $22 \mathrm{~km}$ ) was surveyed twice from solo kayaks (two observers) on 1, 2 June and 16, 21 October 2015. This section contains shallow limestone outcroppings that limit access by motorboat.

We used solo kayaks (two observers) to survey for the three Pseudemys species in the only navigable section of the South Prong, a span of $\sim 12 \mathrm{~km}$ ( $\sim 2 \mathrm{~km}$ upstream and $\sim 10 \mathrm{~km}$ downstream of Thatcher Road) on 26 October and 25, 29 November 2016, and 10 April 2017. A single survey trip on the North Prong was conducted from an accessible point in appropriate habitat at East Keysville Road (CR 676) to the convergence of the North and South prongs in AFCP ( 7 km) on 26 October 2020.

The water-based survey employed binoculars and a digital camera as described for the basking survey from land. We recorded information for each Pseudemys observed as described above. When possible, Suwannee Cooters were hand-captured, given unique identification marks (marginals filed), sexed, measured (max. carapace length $[\mathrm{CL}]$, max. plastron length $[\mathrm{PL}]$, max. carapace width $[\mathrm{CW}]$, max. shell height $[\mathrm{SH}])$ to the nearest $\mathrm{mm}$ ), weighed to the nearest gram, and photographed (carapace and plastron).

\section{Local Community Survey}

We surveyed the local community for information regarding the presence of Suwannee Cooters. A flier (Figure 5) requesting observations was created, and 5,000 copies were distributed from 21 February-18 September 2015 to residences in communities along the Alafia River, including the North and South prongs. The flier included a phone number and email address for contacting us. In addition, an iNaturalist (www.inaturalist.org) project was created and a link provided on the flier so that observations could be submitted online. Information received from 41 responders led us to visit seven sites (two observers), four of which were checked a second time.

\section{Survey on Conservation Lands}

We surveyed Alderman's Ford Nature Preserve (AFNP; 6 June, 1 August, 27 October, and 10 November 2015) and Lithia Springs Conservation Park (LSCP; 27 July 


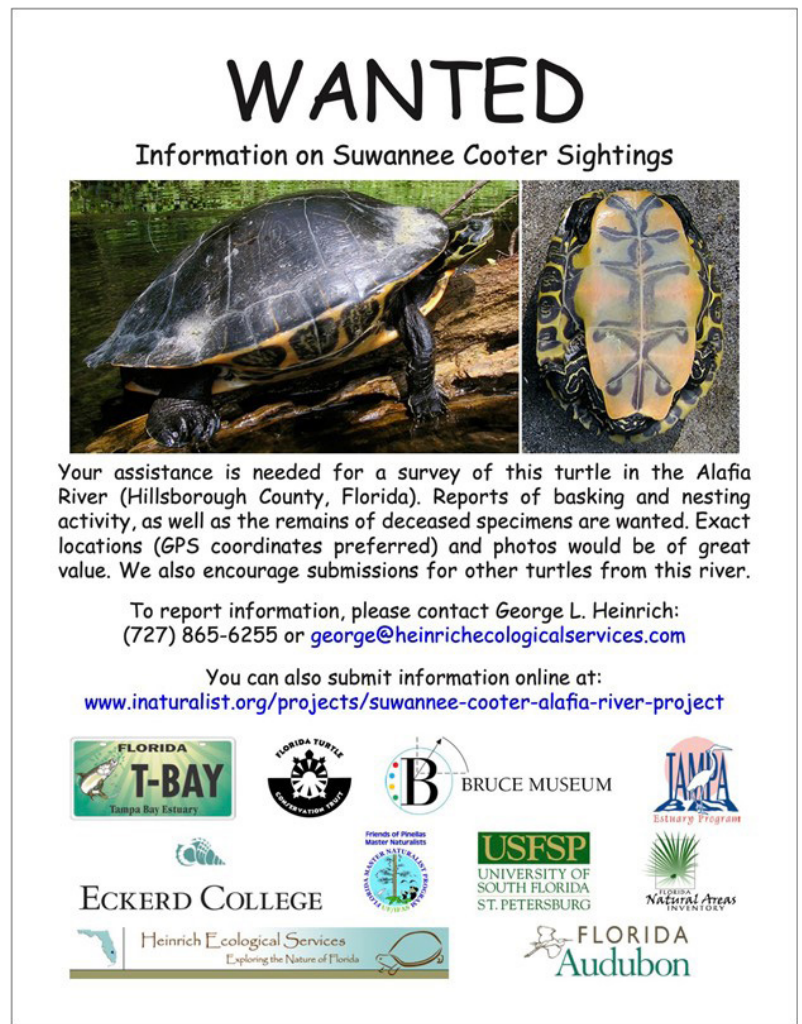

Fig. 5. "Wanted: Information on Suwannee Cooter Sightings" flier.

2015) for skeletal remains and depredated nests using 1-5 surveyors. Collected material was deposited at the Florida Museum of Natural History. At LSCP, we used snorkeling (two swimmers) to search for turtles in two short spring runs associated with Lithia Spring Major and Lithia Spring Minor on 2 June and 21 October 2015. This was the only area where water clarity and legal access allowed us to use this technique. We also surveyed (2 observers) the same spring runs and associated shoreline from land on 17 February, 21 April, 13 May, and 27 June 2015.

\section{Land Status}

We used 2015 aerial imagery in ArcMap and 2020 imagery in Google Earth in an attempt to quantify shoreline hardening and proximity to development (residential, business, and paved roads) within 60 $\mathrm{m}$ of all Suwannee Cooter observations. ArcMap was also used to measure length of shoreline in private vs. designated conservation lands, as documented by the Florida Natural Areas Inventory (FNAI 2020), within the entire river system stretch documented to support this turtle. Because some conservation lands bordered only one side of the river (and/or prongs), we made separate determinations for each side (principally north of main river/east of South Prong, and south of main river/west of South Prong).

\section{RESULTS}

Utilizing multiple survey methods, we observed $P$. C. suwanniensis at 65 locations spanning an uninterrupted stretch of $\sim 47$ linear $\mathrm{km}$ within the Alafia River system (Figures 6-8). While most observations were made on

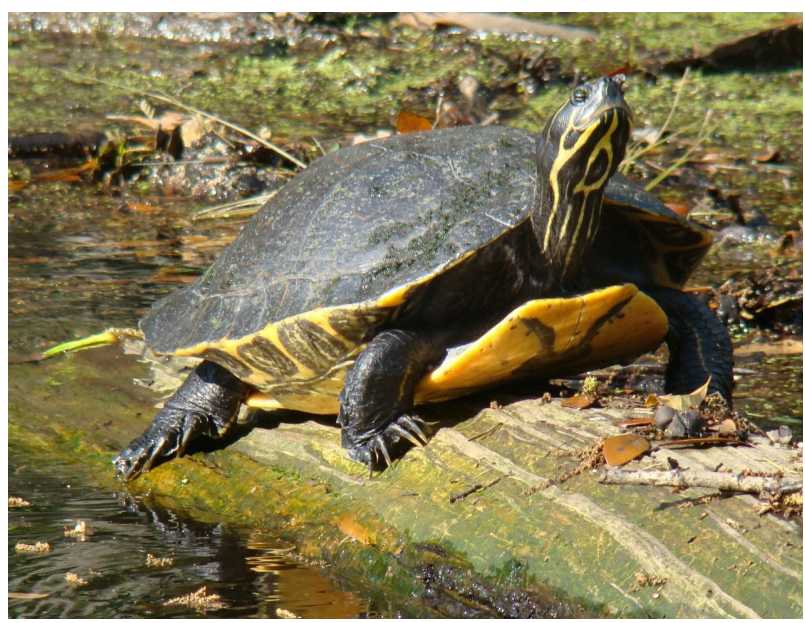

Fig. 6. Basking adult female Pseudemys concinna suwanniensis in the Alafia River (Hillsborough County, Florida). Photograph by George L. Heinrich.

the main river (59), a small number of sightings were also recorded from the North Prong (1) and South Prong (5).

\section{Basking Survey from Land}

This method produced seven GPS points (1 on North Prong, 6 on main river) representing a total of nine Suwannee Cooters (1 juvenile, 8 adults; Table 1, Figure $8)$; these included one male, four females, and four of undetermined sex. Eight individuals were observed basking on embedded or sweeper logs, and a single turtle was seen swimming in the water.

\section{Basking Survey from Water}

The basking survey from water documented 50 GPS points ( 4 on South Prong, 46 on main river) representing a minimum number of 59 P. C. suwanniensis sightings (Table 1, Figure 8). Surveying the main river twice (convergence of the North and South prongs to Williams Park at US 41) allowed us to collect additional GPS points, the primary goal of this project. Therefore, counts may

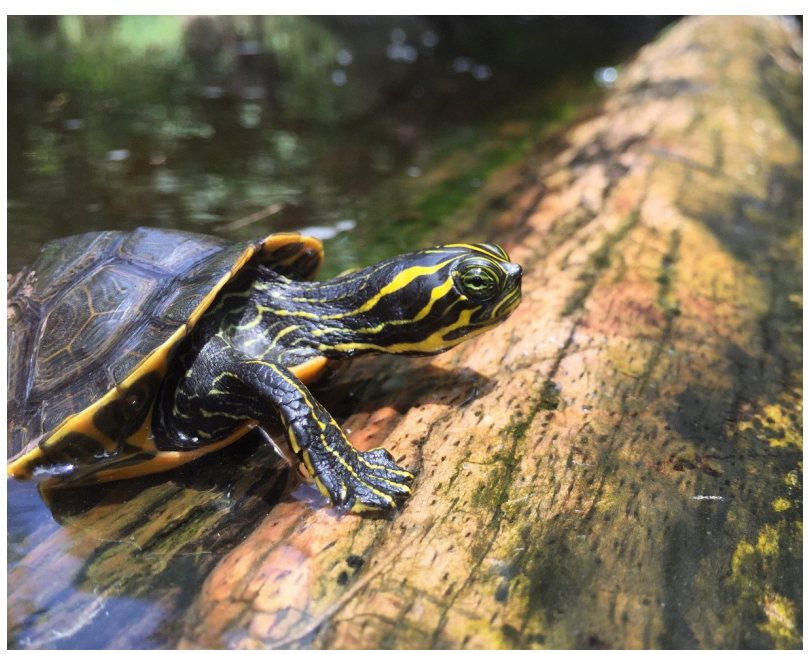

Fig. 7. Basking juvenile Pseudemys concinna suwanniensis in the Alafia River (Hillsborough County, Florida). Photograph by Timothy J. Walsh. 
Table 1. Results from Pseudemys concinna suwanniensis distributional survey in the Alafia River (Hillsborough County, Florida). Number of GPS points (river section), number of turtles sighted, age class, sex, and activity presented by method.

\begin{tabular}{|c|c|c|c|c|c|}
\hline Method & $\begin{array}{l}\text { Number of GPS } \\
\text { Points (river } \\
\text { section) }\end{array}$ & $\begin{array}{c}\text { Number of } \\
\text { Pseudemys } c . \\
\text { suwanniensis }\end{array}$ & Age Class & Sex & Activity \\
\hline $\begin{array}{l}\text { Basking Survey } \\
\text { from Land }\end{array}$ & $\begin{array}{c}7 \text { (1 North Prong, } 6 \\
\text { main river) }\end{array}$ & 9 & 1 juvenile, 8 adults & $\begin{array}{c}1 \text { male, } 4 \text { females, } \\
4 \text { undetermined } \\
\text { sex }\end{array}$ & $\begin{array}{l}8 \text { basking on } \\
\text { embedded or } \\
\text { sweeper logs, } 1 \\
\text { swimming }\end{array}$ \\
\hline $\begin{array}{l}\text { Basking Survey } \\
\text { from Water }\end{array}$ & $\begin{array}{l}50 \text { (4 South Prong, } \\
46 \text { main river) }\end{array}$ & minimum of 59 & $\begin{array}{c}11 \text { juveniles, } 5 \\
\text { subadults, } 32 \\
\text { adults, remainder } \\
\text { undetermined age } \\
\text { class }\end{array}$ & $\begin{array}{l}6 \text { males, } 1 \text { female, } \\
\text { remainder } \\
\text { undetermined sex }\end{array}$ & $\begin{array}{l}49 \text { basking on } \\
\text { embedded, } \\
\text { sweeper, or } \\
\text { floating logs, } 1 \\
\text { basking on shore, } \\
3 \text { floating or } \\
\text { swimming }\end{array}$ \\
\hline $\begin{array}{l}\text { Local Community } \\
\text { Survey }\end{array}$ & 4 (4 main river) & 5 & 5 adults & $\begin{array}{c}2 \text { males, } 1 \text { female, } \\
2 \text { undetermined } \\
\text { sex }\end{array}$ & $\begin{array}{l}5 \text { basking on } \\
\text { embedded or } \\
\text { sweeper logs }\end{array}$ \\
\hline $\begin{array}{l}\text { Survey on } \\
\text { Conservation } \\
\text { Lands }\end{array}$ & 2 (2 main river) & $\begin{array}{l}3 \text {, plus } 1 \text { shell of } \\
\text { depredated turtle }\end{array}$ & $\begin{array}{c}1 \text { juvenile, } 2 \\
\text { adults, } 1 \\
\text { undetermined age } \\
\text { class }\end{array}$ & $\begin{array}{c}1 \text { male, } 3 \\
\text { undetermined sex }\end{array}$ & $\begin{array}{l}1 \text { basking on log, } 2 \\
\text { swimming, } 1 \text { dead }\end{array}$ \\
\hline $\begin{array}{l}\text { Miscellaneous } \\
\text { Observations }\end{array}$ & $\begin{array}{l}2 \text { (1 South Prong, } \\
1 \text { main river) }\end{array}$ & 3 & 3 adults & $\begin{array}{c}2 \text { males, } 1 \\
\text { undetermined sex }\end{array}$ & $\begin{array}{l}2 \text { basking on base } \\
\text { of tree, } 1 \text { basking } \\
\text { on embedded log }\end{array}$ \\
\hline Total & 65 & $\begin{array}{c}\text { minimum of } 80 \\
\text { (including } 1 \text { shell } \\
\text { of depredated } \\
\text { turtle) }\end{array}$ & & & \\
\hline
\end{tabular}

represent some individuals that were observed during both trips.

Determining species, age class, and sex were difficult using this method due to viewing distance (up to $75 \mathrm{~m}$ ), vessel movement, and wariness of turtles causing them to abruptly abandon basking sites. Hence, we were only able to confidently classify 11 juveniles, five subadults, and 32 adults ( 6 males, 1 female). Forty-nine turtles were recorded basking on embedded, sweeper, and floating logs, in addition to one basking on shore. Three turtles were seen floating or swimming.

Two juvenile Suwannee Cooters were captured and processed during the course of fieldwork on the main river. At AFNP, we captured a yearling that was basking on a sweeper log (CL $68 \mathrm{~mm}, \mathrm{PL} 62 \mathrm{~mm}, \mathrm{CW} 62 \mathrm{~mm}$, SH $34 \mathrm{~mm}$, mass $53 \mathrm{~g}$ ). We also captured a yearling swimming in the main river at LSCP (CL $53 \mathrm{~mm}, \mathrm{PL} 46$ $\mathrm{mm}, \mathrm{CW} 49 \mathrm{~mm}$, SH $26 \mathrm{~mm}$, mass $25 \mathrm{~g}$ ).

\section{Local Community Survey}

The 5,000 fliers that we distributed generated 41 responses (via emails, phone calls, and iNaturalist) reporting possible Suwannee Cooter observations made by local community residents. Three responses included photographs of nesting females (2) and a single hatchling. The seven sites that were monitored yielded observations of five adult $P$. C. suwanniensis representing four GPS points on the main river (Table 1, Figure 8). These turtles represented two males, one female, and two of undetermined sex, all of which were basking on embedded or sweeper logs.

\section{Survey on Conservation Lands}

The survey on conservation lands along the main river yielded two GPS points (Table 1, Figure 8 ). At LSCP, three Suwannee Cooters were observed in the main river at the mouth of the run associated with Lithia Spring Major. An adult male was observed basking on a log, and two turtles ( 1 adult and 1 of undetermined age class, and both of undetermined sex) were seen swimming next to that log. No turtles were observed during the two times that we searched (from shore) the spring runs associated with Lithia Spring Major and Lithia Spring Minor.

At AFNP, we found a single shell (UF 181849) of a depredated juvenile Suwannee Cooter on the bank of the main river at a powerline right-of-way. Due to its condition, we were limited in regard to collecting morphometric data (PL $48 \mathrm{~mm}, \mathrm{SH} 28 \mathrm{~mm}$ ). We also 


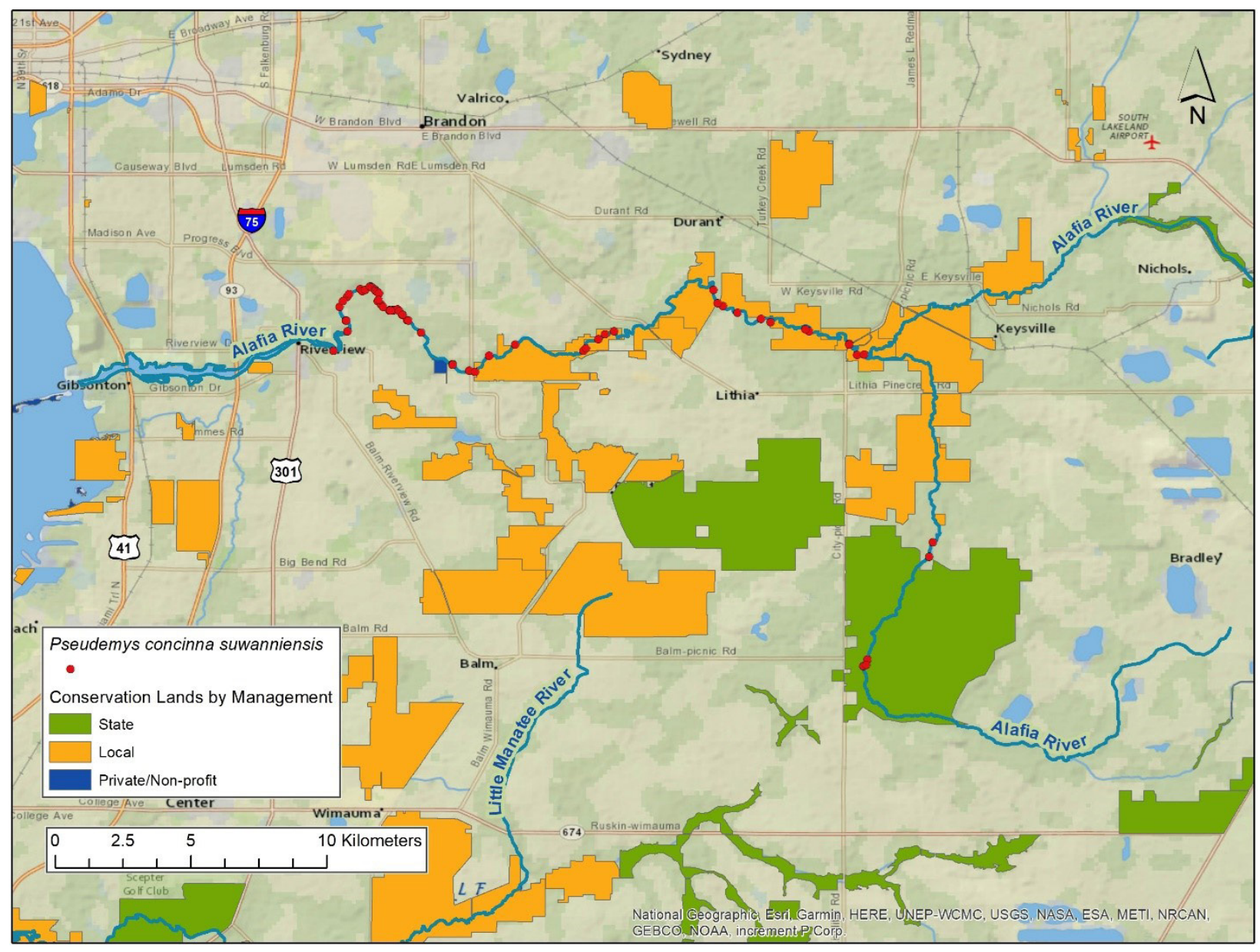

Fig. 8. Distribution of Pseudemys concinna suwanniensis sightings $(\mathrm{N}=65)$ in the Alafia River (Hillsborough County, Florida) based on this study. At this scale, some nearby observations are obscured by others.

observed what appeared to be an abandoned nesting attempt (uncovered three-hole nest containing no eggs) by either a $P$. c. suwanniensis or $P$. f. peninsularis.

\section{Miscellaneous Observations}

Two GPS points were produced tangentially to other fieldwork and could not be assigned to one of the four survey methods (Table 1, Figure 8). Two adult Suwannee Cooters ( 1 male, 1 of undetermined sex) were observed basking on the trunk of a live tree in a flooded cow pasture along the South Prong at Jameson Road. An adult male $P$. c. suwanniensis was seen basking on an embedded log in the main river at McMullen Loop Road, $1.3 \mathrm{~km}$ upriver from US 301.

\section{Land Status}

Because of canopy overhang along the river, only three instances of shoreline hardening were readily observable (using ArcMap and 2020 imagery in Google Earth) adjacent to the 65 points at which Suwannee Cooters were observed. Based on observations from watercraft during the field survey, we know the actual number to have been higher. The presence of residential and business development, as well as paved roads within $60 \mathrm{~m}$ of Suwannee Cooter sightings, therefore served as a proxy. Thirty-eight sites (58\%) were within $60 \mathrm{~m}$ of hardened development, vs. $27(42 \%)$ that were not.
Conservation lands line much of the main river and South Prong within the $47.6 \mathrm{~km}$ stretch identified as Suwannee Cooter habitat (Table 2, Figure 8). The continuous shoreline comprising the northern bank of the main river, eastern bank of the South Prong, and lowermost North Prong includes $22.3 \mathrm{~km}$ of private lands $(46.8 \%)$ and $25.3 \mathrm{~km}$ of lands in conservation (53.2\%). Protection is even greater on the main river's southern bank and adjoining western bank of the South Prong, with $30.6 \mathrm{~km}(65.2 \%)$ in conservation and $16.3 \mathrm{~km}(34.8 \%)$ still private.

\section{Other Herpetofaunal Species Documented}

In addition to the three Pseudemys species, we also documented the following herpetofauna during the course of this study: Southern Toad (Anaxyrus terrestris), Green Treefrog (Hyla cinerea), Cuban Treefrog (Osteopilus septentrionalis; non-native), American Alligator (Alligator mississippiensis), Florida Chicken Turtle (Deirochelys reticularia chrysea), False Map Turtle (Graptemys pseudogeographica; non-native), Red-eared Slider (Trachemys scripta elegans; non-native), Striped Mud Turtle (Kinosternon baurii), Gopher Tortoise (Gopherus polyphemus), Florida Softshell Turtle (Apalone ferox), Brown Anole (Anolis sagrei; non-native), Eastern Sixlined Racerunner (Aspidoscelis s. sexlineata), Eastern Fence Lizard (Sceloporus undulatus), Southern Black 
Table 2. Alafia River conservation lands (Hillsborough County, Florida) within known occurrence of Pseudemys concinna suwanniensis presented from upstream to downstream (South Prong to just below Bell Shoals Road on main river). Alafia River State Park and Alafia River Corridor are on South Prong; all other units are along main river. SWFWMD: Southwest Florida Water Management District.

\begin{tabular}{|c|c|c|c|c|}
\hline Conservation Unit & Side of river/stream & Owners & Lead Manager & Acres \\
\hline Alafia River State Park & both & State & State & 7,718 \\
\hline Alafia River Corridor & both & SWFWMD, County & County & 5,148 \\
\hline Alderman's Ford Conservation Park & both & County & County & 597 \\
\hline Alderman's Ford Nature Preserve & both & State, County & County & 971 \\
\hline Boy Scout Conservation Easement & south & Boy Scouts of America & County & 486 \\
\hline Boy Scout & both (disjunct tracts) & County & County & 602 \\
\hline Fish Hawk Creek Nature Preserve & both & County, SWFWMD & County & 2,551 \\
\hline Lithia Springs Conservation Park & both & The Mosaic Company & County & 160 \\
\hline Myron and Helen Gibbons Nature Preserve & south & Tampa Bay Conservancy & Tampa Bay Conservancy & 58 \\
\hline Total acres & & & & 18,291 \\
\hline
\end{tabular}

Racer (Coluber constrictor priapus), and Florida Water Snake (Nerodia fasciata pictiventris). Six T. s. elegans were observed both in the river and on land, including 3 roadkilled hatchlings. Population levels of this invasive, non-native subspecies should be monitored (Ernst and Lovich 2009).

\section{DISCUSSION}

Our study is novel in examining the distribution of $P$. c. suwanniensis throughout an entire river catchment; this is important because the Alafia River is likely the subspecies' stronghold in the southern portion of its range, based on our studies of this and other regional drainages (Heinrich et al. 2015; Walsh and Heinrich 2015, 2016; Heinrich and Walsh 2016, 2019). In this paper, we report what we observed to be the upstream and downstream limits of Suwannee Cooters and suggest potential factors limiting their distribution. We document a reduction in spring use based on historical records and anecdotally assess the level of current threats to the subspecies in the catchment. We also inform management by calculating that more than half of the river stretches occupied by $P$. C. suwanniensis are bordered by conservation lands. The distribution of conservation fliers to the public made a minor contribution to the distributional data set, but provided valuable, rare information on nesting sites and likely raised awareness of Suwannee Cooters in the river system.

Suwannee Cooters were not observed beyond $\sim 0.22$ $\mathrm{km}$ upstream in the North Prong and $\sim 22 \mathrm{~km}$ upstream in the South Prong, likely due to unsuitable habitat further upstream. The narrow prongs have abundant potential basking sites but less open canopy, and currents are slower than typically favored by $P$. C. suwanniensis (Jackson 2006). The most downstream observation in the main river was at McMullen Loop Road $(1.3 \mathrm{~km}$ upriver from US 301). Beyond this point the tidallyinfluenced river widens and basking structures become sparse. Although turtles may occur in the lower section approaching the river mouth, lack of visible basking sites downriver of Williams Park at US 41 precluded its inclusion in our survey. This subspecies has been documented to occur, at least occasionally, in brackish coastal waters (Carr 1940, 1952; Carr and Goin 1955; Jackson 2006). We did not have legal access to Buckhorn Main Spring and Buckhorn Creek (the mouth of which is located at a high-use recreational area on the river), but did document Suwannee Cooters in the main river near the creek mouth.

Our study, combined with other research and surveys, strongly suggests that the Alafia River system is the stronghold for this obligatory riverine species in the southern portion of the range. The species occurs in a few rivers to the south of the Alafia River (Heinrich and Walsh 2016, 2019), although population densities appear to be much lower. Moreover, the Alafia River differs from most of the rivers occupied by northern populations of Suwannee Cooters. Most studies of $P$. C. suwanniensis have been conducted with populations inhabiting the relatively clear waters of spring-fed river systems within the subspecies' northern range (Giovanetto 1992, Meylan et al. 1992, Jackson and Walker 1997, Huestis and Meylan 2004, Chapin and Meylan 2011, Johnston et al. 2016, Munscher 2017, Johnston et al. 2020). Water clarity in these habitats allows for the use of snorkeling and hand-capture; this technique (mask only) was used in the earliest fieldwork on Suwannee cooters by Marchand (1942) in Rainbow Run (Marion County, Florida). A period of reduced tannin load and greater water clarity in the normally tannic Santa Fe River (Alachua and Columbia counties, Florida) made use of snorkeling and hand-capture possible during a mark-recapture study (Kornilev et al. 2010). Jackson and Walker (1997) employed only hand-captures on land during their study of nesting turtles at Wakulla Springs State Park (Wakulla County, Florida). Other studies have included basking surveys and trapping, essential techniques in blackwater habitats that preclude the use of snorkeling (Jackson 1997, 2002; Ballou et al. 2016). Basking surveys in rivers and streams in the southern portion of the range are needed to confirm that the Alafia River is the southern stronghold of the species.

The survey conducted on conservation lands produced only 2 GPS points, observations of basking/swimming 
turtles at LSCP and a single shell of a depredated juvenile at AFNP. Records of Suwannee Cooters were reported from Lithia Spring Major in 1953 and 1964-1968 (Heinrich et al. 2015), but no sightings were made during our binocular survey from land and while snorkeling. This spring has been a popular public recreational site since 1957, and the substrate of this $\sim 4,332 \mathrm{~m}^{2}$ human-modified swimming area is now bare white sand with some algae. Surveying for intact or depredated nests at LSCP and AFNP resulted in a single observation of a three-hole nest containing no eggs at the latter. However, because both $P$. C. suwanniensis and $P$. $f$. peninsularis construct three-hole nests, we were unable to confirm identification of the species (Carr 1952; Jackson and Walker 1997, Jackson 2006).

Several factors are likely to threaten this population. Situation of the Alafia River within a major phosphate mining region makes water quality degradation from industrial accidents a foremost concern (Cardinale 1998; Jackson 2005, 2006; Heinrich et al. 2015). Other threats include reduction of natural aquatic vegetation (Auffenberg 1978; Jackson 1992, 2005, 2006), loss or removal of deadwood (basking structures; Lindeman 1999, 2013; Bodie 2001), disturbance from recreational boat traffic (Moore and Seigel 2006), boat strikes (Heinrich et al. 2012), and degradation of nesting habitat by feral hogs (Sus scrofa; Lewis et al. 1994, Ditchkoff and West 2007). Although collection of turtles for human consumption has been a major threat elsewhere in the past (Jackson 2005, 2006; Heinrich et al. 2010), we found no evidence of such during the course of the current study. Monitoring of existing and potential threats to both aquatic and nesting habitats of $P, C$. suwanniensis is critical to this turtle's future conservation and management (Jackson 2006, Heinrich et al. 2015). Positive management actions beneficial to riverine turtle populations include maintaining water quality that will support diverse forage species, protecting basking sites and preventing their removal, and restricting shoreline hardening that can prevent access to nesting habitat.

On a positive note, more than half of the land (53.2$65.2 \%$ ) on both sides of riverine habitat that we identified as occupied by the Suwannee Cooter is in some form of conservation management. Turtles are not the primary focus of conservation on any unit, however, so education of agencies and staff managing these lands is vital to assure that management activities are beneficial and not detrimental to their turtle faunas. Additionally, any opportunities to bring further undeveloped private lands along this river system into conservation should be pursued. Clearly, benefits to protecting this riverine ecosystem would extend far beyond turtles.

The local community survey featuring distribution of 5,000 fliers in residential areas adjacent to the Alafia River produced only 4 GPS points, all of which occurred in areas where other locations of Suwannee Cooters were identified during the basking survey from water. Of particular importance, however, was that the fliers yielded submissions of photographs that documented the only two confirmed nesting locations known to us. Although this method was both labor-intensive and costly, it likely enhanced public awareness of Suwannee Cooters and the ecological importance of the river. In general, we suggest that this method would best be reserved for surveys where finding turtles is expected to be more difficult and much less likely.
There were limitations to our study. Suwannee Cooters, like many emydids, are ideal candidates for basking surveys focused on presence and distribution (Lindeman 1999, Enge and Wallace 2008). However, weather conditions (e.g., air temperature, rain, and cloud cover) can negatively affect basking activity and make it difficult to identify species, quantify numbers, and interpret results. That two other similar-looking species of Pseudemys occur sympatrically in Gulf Coast river systems within the Suwannee Cooter's range presents additional challenges. All of these factors can contribute to varied results when repeating surveys of the same area.

This paper reports on the first field study of $P$. C. suwanniensis in a blackwater river system within the southern portion of the subspecies' range. Further research on Suwannee Cooters in the Alafia River is needed to better understand what appears to be the largest population of this subspecies within its southern range. Our study provides a platform for future research and for conservation and management of a critical population of this turtle. In this light, we initiated a markrecapture project in 2019.

\section{ACKNOWLEDGEMENTS}

Peter A. Meylan (Eckerd College), Jeanne Murphy (Friends of Pinellas Master Naturalists), and Melanie Riedinger-Whitmore and Thomas J. Whitmore (University of South Florida) assisted with volunteer recruitment. We thank Trent Adamson, Janet Anschuetz, Andrew Arnold, Jennifer Buchanan, Jim Caldwell, Macy Campbell Mary Anne Campbell, Jo Campo, Bruce Donald Colin, Stephanie Coutant, Laurel Dodson, Logan Dodson, Terry Dunham, Andrew Farren, R. David Goodwin, Rosemary Jackson, Robert Krause, Marta Leach, Patty Moore, Kim Munshower, Riley Munshower, Tom Paczkowski, Peter Robison, Carol Vanryn, Timmy Vanryn, Jessica A. Waltman, Randy Wright, and Ray Wunderlich for assistance with fieldwork. Ann Paul and Mark Rachal (Audubon Florida) provided boat transportation, and Bryan Hughes (Alderman's Ford Conservation Park) and Wayne Rowe (Lithia Springs Conservation Park) kindly assisted with logistical concerns. Peter V. Lindeman (Edinboro University of Pennsylvania) assisted with identification of a Graptemys species. Amy Knight (Florida Natural Areas Inventory) graciously assisted with GIS analysis of data and evaluation of conservation lands, Nathan Pasco (Florida Natural Areas Inventory) produced the map showing locations of turtle sightings and conservation lands, David J. DeWitt (Southwest Florida Water Management District) provided a base map used to produce our map of Florida rivers, and Kate Dzikiewicz (Bruce Museum) assisted with graphic design. This project was supported by a grant from the Tampa Bay Estuary Program and funding from the Florida Turtle Conservation Trust. Research was conducted under Florida Fish and Wildlife Conservation Commission Scientific Collecting Permit Number LSSC-15-00019, Florida Department of Environmental Protection Permit Number 06011524, and authorization from Hillsborough County Conservation \& Environmental Lands Management. This manuscript is dedicated to the memory of David S. Lee, who kindly shared his knowledge of the presence of Suwannee cooters in the Alafia River in the 1960s. 


\section{LITERATURE CITED}

Auffenberg, W. 1978. Threatened: Suwannee cooter, Chrysemys concinna suwanniensis (Carr). Pp. 32-33. In R.W. McDiarmid (Ed.), Amphibians and Reptiles, Rare and Endangered Biota of Florida, Vol. 3. University Presses of Florida, Gainesville.

Ballou, A.R., A.C. Deyle, and D.R. Jackson. 2016. Geographic Distribution: Pseudemys concinna suwanniensis (Suwannee Cooter). Herpetological Review 47(2):253-254.

Bodie, J.R. 2001. Stream and riparian management for freshwater turtles. Journal of Environmental Management 62:443-455.

Cardinale, T. 1998. Mulberry Phosphates Inc. - December 1997 acid spill: Water quality impacts on Alafia River and Tampa Bay. Water Management Division Report, Environmental Protection Commission of Hillsborough County, Florida. 79 pp.

Carr, A.F., Jr. 1935. The identity and status of two turtles of the genus Pseudemys. Copeia 1935(3):147-148.

Carr, A.F., Jr. 1940. A contribution to the herpetology of Florida. University of Florida Publication, Biological Science Series 3(1):1-118.

Carr, A. 1952. Handbook of Turtles: The Turtles of the United States, Canada, and Baja California. Comstock Publishing Associates, Cornell University Press, Ithaca, NY. 542 pp.

Carr, A. and C.J. Goin. 1955. Guide to the Reptiles, Amphibians and Fresh-water Fishes of Florida. University of Florida Press, Gainesville. 341 pp.

Chapin, K.J. and P.A. Meylan. 2011. Turtle populations at a heavily used recreational site: Ichetucknee Springs State Park, Columbia County, Florida. Herpetological Conservation and Biology 6(1):51-60.

Ditchkoff, S.S. and B.C. West. 2007. Ecology and management of feral hogs. Human-Wildlife Conflicts $1(2): 149-151$.

Enge, K.M. and G.E. Wallace. 2008. Basking survey of map turtles (Graptemys) in the Choctawhatchee and Ochlockonee rivers, Florida and Alabama. Florida Scientist 71(4):310-322.

Ernst, C.H. and J.E. Lovich. 2009. Turtles of the United States and Canada. $2^{\text {nd }}$ ed. The John Hopkins University Press, Baltimore, Maryland. 827 pp.

Florida Fish and Wildlife Conservation Commission. 2013. A species action plan for the Suwannee Cooter Pseudemys concinna suwanniensis. Final draft. Tallahassee, Florida. 46 pp. Web. https://myfwc.com/media/2150/ suwannee-cooter-species-action-plan-final-draft.pdf. Accessed on 21 June 2020.

Florida Natural Areas Inventory. 2020. Florida Conservation Lands, June 2020. Web. https://www.fnai.org/ webmaps/ConLandsMap/. Accessed on 27 September 2020.

Giovanetto, L.A. 1992. Population ecology and relative abundance of sympatric freshwater turtles in the headwaters of two spring-fed rivers in western peninsular Florida. Ph.D. dissertation. Florida Institute of Technology, Melbourne, Florida.

Heinrich, G.L., D.R. Jackson, T.J. Walsh, and D.S. Lee. 2015. Southernmost occurrence of the Suwannee cooter, Pseudemys concinna suwanniensis (Testudines: Emydidae). Journal of North American Herpetology 2015(1):53-59.

Heinrich, G.L. and T.J. Walsh. 2016. Geographic Distribution: Pseudemys concinna suwanniensis (Suwannee Cooter). Herpetological Review 47(3):422.
Heinrich, G.L. and T.J. Walsh. 2019. Geographic Distribution: Pseudemys concinna suwanniensis (Suwannee Cooter). Herpetological Review 50(1):100-101.

Heinrich, G.L., T.J. Walsh, D.R. Jackson, and B.K. Atkinson. 2012. Boat strikes: a threat to the Suwannee cooter (Pseudemys concinna suwanniensis). Herpetological Conservation and Biology 7(3):349-357.

Heinrich, G.L., T.J. Walsh, N.M. Mattheus, J.A. Butler, and P.C.H. Pritchard. 2010. Discovery of a modern-day midden: continued exploitation of the Suwannee cooter, Pseudemys concinna suwanniensis, and implications for conservation. Florida Scientist 73(1):14-19.

Huestis, D.L. and P.A. Meylan. 2004. The turtles of Rainbow Run (Marion County, Florida): observations on the genus Pseudemys. Southeastern Naturalist 3(4):595612.

Jackson, D.R. 1992. Species of Special Concern: River cooter, Pseudemys concinna (Le Conte). Pp. 166-170. In P.E. Moler (Ed.), Amphibians and Reptiles, Rare and Endangered Biota of Florida, Vol. 3. University Press of Florida, Gainesville.

Jackson, D.R. 1995. Systematics of the Pseudemys concinna-floridana complex (Testudines: Emydidae): an alternative interpretation. Chelonian Conservation and Biology 1(4):329-333.

Jackson, D.R. 1997. Geographic Distribution: Pseudemys concinna suwanniensis (Suwannee River Cooter). Herpetological Review 28(2):94

Jackson, D.R. 2002. Survey of an important distributional gap in the Florida range of the river cooter and other freshwater turtles. Final Report. Florida Fish and Wildlife Conservation Commission, Tallahassee. 27 pp.

Jackson, D.R. 2005. Florida Rivers and Turtles: An Interdependence. Pp. 163-168. In Meshaka, W.E., Jr. and K.J. Babbitt (Eds.), Amphibians and Reptiles: Status and Conservation in Florida. Krieger Publishing Company, Malabar, Florida.

Jackson, D.R. 2006. Pseudemys concinna - River Cooter. Pp. 325-337. In Meylan, P.A. (Ed.), Biology and Conservation of Florida Turtles. Chelonian Research Monographs No. 3. Chelonian Research Foundation, Lunenburg, Massachusetts.

Jackson, D.R. and R.N. Walker. 1997. Reproduction in the Suwannee cooter, Pseudemys concinna suwanniensis. Bulletin of the Florida Museum Natural History 41(2):69-167.

Johnston, G.R., J.C. Mitchell, E.C. Munscher, G.A. Shemitz, P.L. Butt, S. Cole, and T. Hootman. 2020. Temporal variation in a turtle assemblage inhabiting a Florida spring-fed river. Southeastern Naturalist 19(2):271282.

Johnston, G.R., J.C. Mitchell, E. Suarez, T. Morris, G.A. Shemitz, P.L. Butt, and R.L. Knight. 2016. The Santa Fe River in northern Florida: effect of habitat heterogeneity on turtle populations. Bulletin of the Florida Museum of Natural History 54(5):69-103.

Kornilev, Y.V., C.K. Dodd, Jr., and G.R. Johnston. 2010. Linear home range, movement, and spatial distribution of the Suwannee cooter (Pseudemys concinna suwanniensis) in a blackwater river. Chelonian Conservation and Biology 9(2):196-204.

Krysko, K.L., K.M. Enge, and P.E. Moler (Eds.). 2019. Amphibians and Reptiles of Florida. University of Florida Press, Gainesville. 706 pp.

Lewis, T.E., G.O. Bailey, and H.L. Edmiston. 1994. Effects of predator control on sea turtle nest success on the barrier islands of Apalachicola Bay. Pp. 242-243. In K.A. 
Bjorndal, A.B. Bolten, D.A. Johnson, and P.J. Eliazar (Compilers), Proceedings of the Fourteenth Annual Symposium on Sea Turtle Biology and Conservation. NOAA Technical Memorandum NMFS-SEFSC-351.

Lindeman, P.V. 1999. Surveys of basking map turtles Graptemys spp. in three river drainages and the importance of deadwood abundance. Biological Conservation 88(1999):33-42.

Lindeman, P.V. 2013. The Map Turtle and Sawback Atlas: Ecology, Evolution, Distribution, and Conservation. University of Oklahoma Press, Norman. 460 pp.

Marchand, L.J. 1942. A contribution to a knowledge of the natural history of certain freshwater turtles. Master's thesis. University of Florida, Gainesville.

Meylan, P.A. (Ed.). 2006. Biology and Conservation of Florida Turtles. Chelonian Research Monographs No. 3, Chelonian Research Foundation, Lunenburg, Massachusetts. $376 \mathrm{pp}$.

Meylan, P.A., C.A. Stevens, M.E. Barnwell, and E.D. Dohm. 1992. Observations on the turtle community of Rainbow Run, Marion Co., Florida. Florida Scientist 55(4):219-228.

Moore, M.J.C. and R.A. Seigel. 2006. No place to nest or bask: Effects of human disturbance on the nesting and basking habits of yellow-blotched map turtles (Graptemys flavimaculata). Biological Conservation 130(2006):386-393.

Munscher, E.C., A.D. Walde, E.M. Walton, N. Salvatico, B.P. Butterfield, W. Osborne, C. McAvinchey, and J.B. Hauge. 2017. Turtle survey of Weeki Wachee Springs State Park reveals more than mermaids. Herpetology Notes 10:601-609.

Parsons. 2008. Alderman's Ford Park land management and land use plan. Prepared for Hillsborough County Parks, Recreation and Conservation Department, Tampa, Florida. 40 pp.

Pope, C.H. 1939. Turtles of the United States \& Canada. Alfred A. Knopf, New York. $343+v$ pp.

Scott, T.M., G.H. Means, R.P. Meegan, R.C. Means, S.B. Upchurch, R.E. Copeland, J. Jones, T. Roberts, and A. Willet. 2004. Springs of Florida. Florida Geological Survey Bulletin No. 66, Florida Department of Environmental Protection, Division of Resource Assessment and Management, Tallahassee. 377 pp.
Seidel, M.E. 1981. A taxonomic analysis of pseudemyd turtles (Testudines: Emydidae) from the New River, and phenetic relationships in the subgenus Pseudemys. Brimleyana 6:25-44.

Seidel, M.E. 1994. Morphometric analysis and taxonomy of cooter and red-bellied turtles in the North American genus Pseudemys (Emydidae). Chelonian Conservation and Biology 1(2):117-130.

Seidel, M.E. and M.J. Dreslik. 1996. Pseudemys concinna (LeConte), River Cooter. Catalogue of American Amphibians and Reptiles 626.1-626.12. Society for the Study of Amphibians and Reptiles.

Stoker, Y.E., V.A. Levesque, and W.M. Woodham. 1996. The effect of discharge and water quality of the Alafia River, Hillsborough River, and the Tampa Bypass Canal on nutrient loading to Hillsborough Bay, Florida. U.S. Geological Survey, Water-Resources Investigations Report 95-4107, Tallahassee, Florida. 69 pp.

Turtle Taxonomy Working Group [Rhodin, A.G.J., J.B. Iverson, R. Bour, U. Fritz, A. Georges, H.B. Shaffer, and P.P. van Dijk]. 2017. Turtles of the World: Annotated Checklist and Atlas of Taxonomy, Synonymy, Distribution, and Conservation Status ( $8^{\text {th }}$ edition). In Rhodin, A.G.J., J.B. Iverson, P.P. van Dijk, R.A. Saumure, K.A. Buhlmann, P.C.H. Pritchard, and R.A. Mittermeier (Eds.), Conservation Biology of Freshwater Turtles and Tortoises: A Compilation Project of the IUCN/SSC Tortoise and Freshwater Turtle Specialist Group. CheIonian Research Monographs 7:1-292. doi: 10.3854/ crm.7.checklist.atlas.v8.2017. Chelonian Research Foundation, Lunenburg, Massachusetts.

Walsh, T.J. and G.L. Heinrich. 2015. Geographic Distribution: Pseudemys suwanniensis (Suwannee Cooter). Herpetological Review 46(3):382.

Walsh, T.J. and G.L. Heinrich. 2016. Geographic Distribution: Pseudemys concinna suwanniensis (Suwannee Cooter). Herpetological Review 47(3):422-423.

Ward, J.P. 1984. Relationships of chrysemyd turtles of North America (Testudines: Emydidae). Special Publications, The Museum, Texas Tech University 21:1-50. 